\title{
Chemical composition and physical characteristics of cowpea haulms as forage for ruminants
}

\author{
H.K. Mokoboki, K.K. Ayisi and L.R. Ndlovu\# \\ Dept of Animal Production, University Of The North, P Bag X 1106, Sovenga, 0727 \\ \#e-mail:NdlovuL@unin.unorth.ac.za
}

\section{Introduction}

Cowpea ( Vigna unguiculata) is a major grain legume grown by small- scale farmers in the Northern Province of South Africa. The crop is indigenous to Africa and is used extensively in many cropping systems throughout Africa (Eaglesham et al., 1981). Cowpea straws are potential supplementary feed for ruminants in the dry season. Cowpea straws are likely to have higher crude protein than cereal straws and may thus improve digestibility of cereal straws if used together. However, cowpea straws may contain anti-nutritional factors such as tannins and total phenols which affect animal performance. The protein and tannin content of cowpea straws is likely to be affected by variety and growth environment. Straws of varieties adapted to Northern Province have not been evaluated for their content of these constituents. Whilst animal intake and utilisation are the ultimate test of forage suitability, the procedures are unsuitable when large number of forage germ-plasm are to be screened. Chemical and physical characteristics that are known to affect intake and utilisation are often used in such circumstances. The main aim of this research was to determine the effect of variety on physical and chemical characteristics of straws of long season cowpeas and also to determine if haulms of varieties that retain greenness longer will have a better nutritional value than those that dry early.

\section{Materials and Methods}

Sixteen forages used in the experiment were grown under similar soil and management conditions at the University of the North Experimental Farm using a randomised complete block design. The following varieties were used: TUV11424, CH84, CH15, CH47, IT1948-01F, ENCORE, BECH -WIT, IT83D442, W-A-RED, CH59, IT93K1140, CH55, NWK-SEL, IT85D3850-2, IT87D692-2 and CH14. At harvest the forages were scored for greenness on a scale of 0 to $100 \%$. After harvesting the forages were dried at room temperature and then analysed for content of dry matter, crude protein, total phenols, condensed tannins, packed volume and water retention. Packed volume and water retention were determined following the procedure of Seoane et al., (1983). Dry matter and crude protein content were determined using methods by AOAC, (1984). Total phenolic compounds were extracted with $70 \%$ aqueous acetone from all varieties. The extracts were used to determine total phenols by the Folin-Ciocalteu assay and tannins by the butanol- $\mathrm{HCl}$ assay. All data were subjected to analysis of variance using models that accounted for block and variety effects. If significant $p$ values occurred then comparisons of means was done using Duncan multiple range test. Correlation was used to establish the relationship between greenness and both physical characteristics and chemical composition. Two-way component analysis was used to group varieties into clusters based on their nutritional value. Only seven varieties are presented as they are represented the two extremes.

\section{Results and Discussion}

There were significant varietal effects on both physical characteristics and chemical composition except for total phenols (Table 1). Crude protein content is an important determinant of forage quality, especially in crop residues. Varieties TUV11424 and IT85D385 had crude protein contents of approximately $7 \%$ which is adequate to meet maintenance requirements of sheep and mature cattle. Packed volume and water retention are inversely related to forage intake ( Seoane et al., 1983). Varieties IT1948-01F and IT87D697 which had high packed volume and water retention would make poor supplements. The content of tannins in all varieties was below $5 \%$ DM, the critical value above which tannins interfere with intake, digestion and utilization of forages. There was no correlation between total phenols and packed volume, water retention, dry matter and crude protein $(\mathrm{P}>0.05)$. Greenness was correlated to crude protein $(\mathrm{r}=0.249, \mathrm{P}=0.047)$ and to condensed tannins $(\mathrm{r}=0.328, \mathrm{P}=0.008)$. Varieties TUV11424 and IT85D385 had a high greenness as compared to others and these varieties also had a better nutritional value in terms of crude protein content and low packed volume. There was no correlation between total phenols and packed volume, water retention, dry matter and crude protein content. Inadequate quality and quantity of forages depresses livestock production in smallholder farming systems. Crop residues are 
Short paper and poster abstracts: $38^{\text {th }}$ Congress of the South African Society of Animal Science important contributors to feed resources in this sector and the area planted to cow peas inter-cropped with maize has increased in the last 5 years in Northern Province crop-livestock systems. These results suggest that crop residues of fields where maize is inter-cropped with cowpea varieties such as TUV11424 and IT85D385 are likely to have protein levels adequate to promote fibre digestion in the rumen with no or minimal detrimental effects due to polyphenolics in the cowpea straws. This could reduce live weight losses in ruminant animals in rural areas during the dry season when crop residues are the main feed resource

Table 1 Physical characteristics and chemical composition of cowpea varieties.

\begin{tabular}{llllllll}
\hline Variety & $\begin{array}{c}\text { PKD } \\
(\mathrm{ml})\end{array}$ & $\begin{array}{c}\text { WRTEN } \\
(\mathrm{g} / \mathrm{g})\end{array}$ & $\begin{array}{c}\text { DM } \\
(\%)\end{array}$ & $\begin{array}{l}\text { CP } \\
(\% \mathrm{DM})\end{array}$ & $\begin{array}{l}\text { CT } \\
(\% \mathrm{DM})\end{array}$ & $\begin{array}{l}\text { T. PHEL } \\
(\% \mathrm{DM})\end{array}$ & $\begin{array}{l}\text { GREEN } \\
(\%)\end{array}$ \\
\hline IT1948-01F & $12.33^{\mathrm{a}}$ & $11.40^{\mathrm{b}}$ & $95.60^{\mathrm{cd}}$ & $6.10^{\mathrm{d}}$ & $0.03^{\mathrm{c}}$ & 1.45 & $11.25^{\mathrm{c}}$ \\
IT93K1140 & $12.17^{\mathrm{ab}}$ & $10.68^{\mathrm{c}}$ & $96.25^{\mathrm{b}}$ & $6.92^{\mathrm{b}}$ & $0.04^{\mathrm{bc}}$ & 1.05 & $21.25^{\mathrm{c}}$ \\
TUV11424 & $11.75^{\mathrm{bc}}$ & $9.97^{\mathrm{d}}$ & $95.38^{\mathrm{d}}$ & $7.42^{\mathrm{a}}$ & $0.03^{\mathrm{c}}$ & 1.96 & $56.25^{\mathrm{b}}$ \\
IT87D697 & $11.67^{\mathrm{c}}$ & $11.85^{\mathrm{a}}$ & $96.44^{\mathrm{a}}$ & $5.98^{\mathrm{d}}$ & $0.07^{\mathrm{a}}$ & 1.05 & $29.00^{\mathrm{bc}}$ \\
IT85D385 & $11.33^{\mathrm{cd}}$ & $10.67^{\mathrm{c}}$ & $95.70^{\mathrm{c}}$ & $7.32^{\mathrm{a}}$ & $0.06^{\mathrm{ab}}$ & 1.34 & $93.75^{\mathrm{a}}$ \\
BECH -WIT & $11.00^{\mathrm{d}}$ & $10.53^{\mathrm{c}}$ & $95.73^{\mathrm{c}}$ & $6.47^{\mathrm{c}}$ & $0.03^{\mathrm{c}}$ & 1.34 & $3.75^{\mathrm{c}}$ \\
CH47 & $11.29^{\mathrm{d}}$ & $11.25^{\mathrm{b}}$ & $95.36^{\mathrm{d}}$ & $5.06^{\mathrm{e}}$ & $0.05^{\mathrm{c}}$ & 0.75 & $1.50^{\mathrm{c}}$ \\
MSE & 0.96 & 0.055 & 0.0170 & 0.026 & 0.0003 & 1.1803 & 499.557 \\
df & 173 & 173 & 109 & 109 & 45 & 126 & 45 \\
\hline
\end{tabular}

${ }^{\mathrm{a}, \mathrm{b}, \mathrm{c}}$ Means with different letters are significantly different from each other; MSE : Mean square error; df: Degrees of Freedom $\mathrm{PKD}=$ Packed volume, $\mathrm{WRTEN}=$ Water retention, $\mathrm{DM}=$ Dry matter, $\mathrm{CP}=$ Crude protein,

$\mathrm{CT}=$ Condensed tannin, T.PHEL $=$ Total phenols and GREEN $=$ Greenness.

\section{Conclusion}

Variety significantly affected chemical and physical characteristics of cowpea straws. Straws of varieties IT85D385 and TUV11424 would be valuable as supplements because they have relatively high crude protein content, low water retention and packed volume and retained more greenness at harvest. These varieties are likely to result in high intake and improve animal performance. Varieties IT1948-01F, IT93K1140 and IT87D697 which were high in packed volume and water retention but low in crude protein and greenness are less valuable as supplements.

\section{References}

AOAC,1984. Official methods of analysis. $13^{\text {th }}$ ed. Washington. DC.

Eagelsham, A. R. J. et al., 1981. Soil Biol. Biochem. 13, 169.

Seoane, J. R. et al., 1983. Can. J. Anim. Sci. 63, 367. 